\title{
Calf health and management in smallholder dairy farms in Tanzania
}

\author{
Jelly S. Chang'a $\cdot$ Robinson H. Mdegela $\cdot$ Ruth Ryoba $\cdot$ \\ Torleiv Loken • Olav Reksen
}

Accepted: 13 June 2010 /Published online: 25 June 2010

(C) The Author(s) 2010. This article is published with open access at Springerlink.com

\begin{abstract}
Smallholder farmers' knowledge and practice of dairy calf management on 129 farms with calves less than 10 months of age in Southeastern and Southern Highland areas of Tanzania was assessed. The method of study included both a farm visit and completion of a questionnaire. Most of the farmers were female, with a primary level of education, and majority kept 1-3 milking cows that yielded 6-10 $1 \mathrm{milk} / \mathrm{cow} / \mathrm{day}$. Most of the calves were fed milk using a residual calf suckling system. Weaning age was 3-8 months. Overall, the body condition of the calves was poor, ranged from 1 to 2.5 with a mode of 2 . The majority of the farmers believed that helminthosis was the
\end{abstract}

\section{J. S. Chang'a}

Livestock Research Centre, Ministry of Livestock Development,

P.O. Box 561, Tanga, Tanzania

\section{R. H. Mdegela}

Department of Veterinary Medicine and Public Health,

Faculty of Veterinary Medicine,

Sokoine University of Agriculture,

P.O. Box 3021, Morogoro, Tanzania

e-mail: mdegela@suanet.ac.tz

R. Ryoba

Department of Animal Science and Production,

Faculty of Agriculture, Sokoine University of Agriculture,

P.O. Box 3000, Morogoro, Tanzania

e-mail: rryoba@suanet.ac.tz

\section{J. S. Chang'a $(\bowtie) \cdot$ T. Løken $\cdot$ O. Reksen}

Department of Production Animal Clinical Science,

Norwegian School of Veterinary Sciences,

P.O. Box 8146, Oslo, Norway

e-mail: jelhas2002@yahoo.co.uk

T. Løken

e-mail: Torleiv.Loken@nvh.no

O. Reksen

e-mail: Olav.Reksen@nvh.no most common disease condition affecting the calves; diarrhea was ranked as the second. Calf death was reported by $20 \%$ of the farmers to have occurred in their herd lasting the 2 years prior to the study. Calf body condition score was related to body weight for calves younger than 9 weeks, and older than 23 weeks of age, whereas no such relationship existed in the age group 9 to 23 weeks. The sex distribution was skewed with less male calves being older than 23 weeks. We hypothesize that male calves experience inferior management compared with female calves. This study demonstrates a low level of knowledge on, and poor practices of calf management among the surveyed farmers that suggest the need for educational intervention.

Keywords Body condition score - Calf health . Smallholder dairy farmers $\cdot$ Residual calf suckling

\section{Introduction}

The smallholder dairy production system is an important component of rural livelihood transformation in Tanzania. Farmers usually keep a small number of cattle indoors; the average herd consists of 3-9 crossbred cows (European dairy cattle $\times$ Shorthorn Zebu). The system provides food and income for rural smallholder dairy farmers. However, many farmers experience suboptimal production. The reasons for this are multifactorial; among them are poor livestock management and disease. High levels of calf mortality have limited dairy herd expansion and genetic improvement. In the tropics, mortality rates vary depending on management and severity of draft. The few studies on calf mortality on smallholder farms in Tanzania show mortality that range from 9\% to 45\% (Shoo et al. 1992; Masanja and Matovelo 1993; Chenyambuga and Mseleko 2009). 
Proper nutrition is fundamental for calf growth and for the general profitability of calf rearing enterprises. In young stock, a good nutritional strategy optimizes rumen development and growth while minimizing stress and disease. Livestock housing conditions greatly affects health and productivity. A relationship between housing and health during the rearing period has been described by several authors (Gitau et al. 1994; Wudu et al. 2008). Cleanliness of the barn influences calf health, as calves housed in unclean barns are at higher risk of disease than calves housed in clean barns (Wudu et al. 2008).

Gastrointestinal helminthes are important pathogens which affect young livestock in many tropical and subtropical environments (Keyyu et al. 2005, 2006). Treatment with anthelminthics administered 2-4 times a year, depending on climate and management practices, has been recommended for helminth control (Keyyu et al. 2005, 2009). Diarrhea is one of the most important constraints in food animal production (Lema et al. 2001). Its prevalence appears to be management related especially when calves are housed in unhygienic conditions (Wudu et al. 2008). Diarrhea may be nutritionally induced or caused by infectious agents (viruses, bacteria, fungi, or protozoa). Cryptosporidia is among the protozoa which cause diarrhea, retarded growth, and death in calves. In Tanzania, a previous study revealed the prevalence of cryptosporidiosis to be $19.7 \%$ in smallholder dairy cattle (Swai et al. 2007) and $1.5 \%$ of giardia (Kusiluka et al. 2005).

Good calf rearing is important as it ensures availability of good future replacement stock. In Tanzania, calves in most smallholder dairy farms are not performing well. Most farmers do not have enough knowledge on proper calf-feeding regimes. Apart from that, farmers aim to optimize income by selling more milk and calves are, therefore, underfed. This is more serious in bull calves, resulting lack of bulls in smallholder farms. However, studies conducted on calf management and the impact management has on these calves' health in smallholder farms in Tanzania are very few.

Hence, the primary objective of the present study was to examine the health and performance of dairy calves on smallholder farms in Tanzania. Secondary objectives were: (1) to determine the level of farmers' knowledge and to establish current calf management practices, (2) to assess relationships between single parameters at calf level, and variance components at herd, village, and district levels.

\section{Materials and methods}

Farms and animals

This study was conducted in Mvomero in Southeastern and Njombe in the southern highlands of Tanzania. Mvomero district has a typical tropical climate with biannual rainy and dry seasons. The long rainy season ranges from midFebruary to May and the short rainy season from November to December. The altitude ranges from 380 to $520 \mathrm{~m}$ above sea level with an annual rainfall of 1,500-2,000 mm, and the temperature ranges $15-29^{\circ} \mathrm{C}$. Njombe district has an altitude between 1,600 and 1,800 $\mathrm{m}$ above sea level, annual rainfall of $1,000-1,600 \mathrm{~mm}$, temperature ranges $12-23^{\circ} \mathrm{C}$, and the rainy season is from December to April. The 14 villages included in the study were Lungo, Manyinga, Lusanga, Hembeti, Dihombo, Kichangani and Mhonda in Mvomero and Lunywanywi, Mji mwema, Ibumila, Kichiwa, Itulike, Itunduma, and Mtwango in Njombe. Most of the villages were under the Program for Agricultural and Natural Resource Transformation for Improved Livelihoods project, which aimed to develop an integrated and sustainable dairy production system. Farms with calves less than 10 months of age during the farm visit were included in the study, given a total of 129 smallholder dairy farms and 151 calves. Milk production was the major purpose of keeping the dairy cattle on the study farms.

\section{Questionnaire survey}

A questionnaire which composed of questions on farm data and calf management was used. The questionnaire was pretested in a pilot study and modified before the main survey. The questions included the gender and education background of the responsible personnel, size of the farm, calf rearing practices, feeding and housing of the animals, disease incidence, and disease-control practices (Tables 1 and 2). Information on cow milk production, as well as the breed and age of calves were also recorded.

\section{Calf management}

During the farm visits by the study veterinarian (1st author), an observational assessment of the housing and hygiene was performed. This included making an assessment of the condition of the barn floor (presence of potholes, drainage system, and accumulation of cows' dung) and general hygiene in calf house and its surroundings. Housing hygiene was graded from 1 to 4 (1=very clean, $4=$ very poor; Table 2 ). The feeds that were available to the calves were evaluated according to the type of forage. Different species from the forage bundles were separated and identified. The feed supplements fed were also identified.

Clinical examination

Clinical examinations were performed in a routine manner. The calves' heart girths were measured using 
Table 1 Education level and gender of responsible person on 129 smallholder dairy farms in Tanzania

\begin{tabular}{|c|c|c|c|c|c|}
\hline Variable & Category & Mvomero $(n=53)$ & Njombe $(n=76)$ & Total number & Percent \\
\hline \multirow[t]{4}{*}{ Education level } & No formal education & 3 & 2 & 5 & 4 \\
\hline & Primary school & 38 & 70 & 108 & 84 \\
\hline & Secondary school & 10 & 4 & 14 & 11 \\
\hline & University & 2 & 0 & 2 & 1 \\
\hline \multirow[t]{3}{*}{ Gender } & Shared responsibility & 2 & 3 & 5 & 4 \\
\hline & Female & 32 & 40 & 72 & 56 \\
\hline & Male & 19 & 33 & 52 & 40 \\
\hline
\end{tabular}

a tape measure. This measure was then used to estimate the bodyweight using a formula obtained by correlating the bodyweight with measurements of the heart girth of about 120 crossbred dairy calves between 1 and 9 months of age at Magadu, Animal Science and Mazimbu University dairy farms prior the study. The formula used was Bodyweight $[\mathrm{kg}]=($ Heart girth $[\mathrm{cm}]$ - 67.07)/0.4. Body condition score (BCS) was assessed according to Wildman scale (Wildman et al. 1982), which composed of a $1-5$ scale, with 0.5 point increments. The calves were either Friesian $(n=82)$ or Ayrshire $(n=69)$ crosses.

\section{Statistical analyses}

The statistical software package, STATA 10 was used for the following statistical analyses: The continuous variable age was categorized in three age categories $(0-8,9-23$, and 24-42 weeks) with approximately the same number of calves in each group. The distribution of sexes within each age group was assessed in simple univariate analyses using the Chi-squared test.

BCS was assigned to 126 of the calves with 42, 44, and 40 calves in the age groups $0-8,9-23$ and 2442 weeks, respectively. The relationship between BCS and bodyweight was assessed separately for each age group using ordinary simple linear regression. The difference in BCS between male and female calves was evaluated in a simple univariate analysis using one-way analysis of variance (ANOVA). Similarly, BCS differences between Friesian and Ayrshire crosses were assessed using ANOVA.

For the assessment of the BCS variance components at region, herd and animal level, mixed model analyses (xtmixed) approach in STATA was used. BCS was the continuous outcome variable, and district, village and farm was included as random effect variables in the model. Statistical significance was considered with a $P$ value less than 0.05 in all models.

\section{Results}

Farms and animals

Out of the 129 smallholder dairy farmers, 108 (84\%) had received primary school education, and 72 (56\%) were female (Table 1). The number of cows on the farms was $1-$ 3 in $78(60 \%), 4-6$ in $46(36 \%)$ or $7-9$ in five $(4 \%)$ of the farms. The average milk yield per cow per day as reported by the farmers was $1-51$ in $17(13 \%)$ of the farms, 6-9 1 in $81(63 \%)$, and more than 91 in $31(24 \%)$ of the farms.

\section{Calf management}

Calves were housed separately away from adult animals on $120(93 \%)$ of the farms. The milk feeding regimen on the farm varied between bucket/bottle and residual suckling of the dam. Most farmers, 107 (83\%), practiced a residual calf suckling feeding system (Table 2). All farmers fed their calves twice daily, except one who fed three times a day. Most farmers treated their animals against parasites every three months, the preferred anthelmintics were albendazole, which was used by $99(77 \%)$ and levamizole $30(23 \%)$. Weaning age ranged between 3 and 8 months. Most farmers provided their calves with poor quality food mainly natural grasses and dry crop residues. Only a few provided maize bran in addition to grass, none of the farmers provided protein supplements. Helminthes was reported by the farmers to be the most commonly occurring disease condition amongst the calves; diarrhea was ranked as the second.

On $27(21 \%)$ of the farms, at least one calf had died during the past 2 years. Farmers' perceptions of the cause of death were wide-ranging including diarrhea, helminthes, pneumonia, East Coast fever (ECF), bloat, food poisoning, sudden death, and unknown cause.

Altogether, 151 calves were surveyed. The age of the calves ranged from 1-42 weeks with a median age of 17 weeks. The calves were unevenly distributed by sex; 89 
Table 2 Management factors in 129 smallholder dairy farms in Tanzania as given in a questionnaire survey

\begin{tabular}{|c|c|c|c|}
\hline Factor & $\begin{array}{l}\text { Farms } \\
\text { Category }\end{array}$ & Number $(n)$ & Percent \\
\hline \multirow[t]{3}{*}{ Number of calves on the farm } & 1 & 110 & 85 \\
\hline & 2 & 16 & 13 \\
\hline & 3 & 3 & 2 \\
\hline \multirow[t]{2}{*}{ Type of milk-feeding regimen } & Bucket/bottle & 22 & 17 \\
\hline & Residual calf sucking & 107 & 83 \\
\hline \multirow[t]{2}{*}{ Frequency of feeding milk } & Three times a day & 1 & 1 \\
\hline & Twice a day & 128 & 99 \\
\hline \multirow[t]{3}{*}{ Weaning age } & 3 to 4 months & 91 & 70 \\
\hline & 5 to 6 months & 29 & 23 \\
\hline & 7 to 8 months & 9 & 7 \\
\hline \multirow[t]{2}{*}{ Stall type } & Free stall & 120 & 93 \\
\hline & Individual pen & 9 & 7 \\
\hline \multirow[t]{2}{*}{ Floor type } & Flat & 80 & 62 \\
\hline & Slope & 49 & 38 \\
\hline \multirow[t]{4}{*}{ Frequency of cleaning } & Once daily & 97 & 75 \\
\hline & Twice per day & 23 & 18 \\
\hline & Twice per week & 7 & 5 \\
\hline & Weekly & 2 & 2 \\
\hline \multirow[t]{4}{*}{ Housing hygiene } & Very clean & 16 & 12 \\
\hline & Clean & 50 & 39 \\
\hline & Poor & 41 & 32 \\
\hline & Very poor & 22 & 17 \\
\hline \multirow[t]{2}{*}{ Use of anthelmintics } & No & 14 & 11 \\
\hline & Yes & 115 & 89 \\
\hline \multirow[t]{7}{*}{ Frequency of deworming } & Never & 14 & 11 \\
\hline & Once monthly & 5 & 4 \\
\hline & Every second month & 3 & 2 \\
\hline & Every 3 months & 90 & 70 \\
\hline & Every 4 months & 5 & 4 \\
\hline & Every 6 months & 10 & 8 \\
\hline & Once yearly & 2 & 1 \\
\hline \multirow[t]{6}{*}{ Farmers' perception of the most common disease } & None & 63 & 49 \\
\hline & Helminthes & 38 & 29 \\
\hline & Diarrhea & 22 & 17 \\
\hline & East Coast fever & 3 & 2 \\
\hline & Coughing & 2 & 2 \\
\hline & Pneumonia & 1 & 1 \\
\hline \multirow[t]{2}{*}{ Calf mortality the past 2 years } & No & 102 & 79 \\
\hline & Yes & 27 & 21 \\
\hline Farmers' perception of the & None & 102 & 79 \\
\hline \multirow[t]{8}{*}{ Most common cause of calf death } & East Coast fever & 4 & 3 \\
\hline & Bloat & 1 & 1 \\
\hline & Diarrhea & 5 & 4 \\
\hline & Food poisoning & 2 & 2 \\
\hline & Helminthes & 1 & 1 \\
\hline & Pneumonia & 4 & 3 \\
\hline & Sudden death & 2 & 1 \\
\hline & Unknown cause & 8 & 6 \\
\hline
\end{tabular}


$(58 \%)$ were female and $62(42 \%)$ were male. There was an association between the male: female ratio when divided by age category (Pearson Chi square $=2.13, P=0.02$ ). The sex distribution in the three age groups is displayed in Fig. 1.

\section{Clinical findings}

BCS was assigned to 126 calves and ranged from 1 to 2.5 with a mode of 2 . The association between BCS and weight is displayed separately for the three age strata in Table 3 . There is a linear relationship between BCS and bodyweight for the lowest and highest age group, but no such relationship could be found for calves aged between 9 and 23 weeks. A relatively high proportion of the variance in BCS (35\%) could be explained by the regression on weight for the youngest strata whereas $2 \%$ and $19 \%$ of the variation in BCS could be explained by weight for calves between 9-23 and 24-42 weeks of age, respectively.

BCS was not significantly different between the sexes in any of the age groups. However, female calves aged over 23 weeks tended to have a higher BCS than their male counterparts $(P=0.08)$ with a mean BCS of 1.91(S.E. 0.06) and 1.69 (S.E. 1.11), respectively. No difference in BCS was found between Ayrshire and Friesian crossbred calves.

The assessment of variance components of BCS on district, village, and animal level showed that $96 \%$ of the variance resided at farm level, and $4 \%$ was due to differences between villages (Table 4).

\section{Discussion}

The study revealed that the majority of the responding farmers were female, and they were mostly involved in the enterprises. This indicates that smallholder dairy farming provides self-employment to women and, therefore, contributes to the alleviation of poverty in this particular group. A reason for this could be the results of women supportive nongovernmental organizations (NGOs) which have increased support to rural women in agriculture since the 1990s. For instance; in Mvomero, the introduction of crossbred dairy cows was initiated in 1993 by the foundation for sustainable rural development, a locally based NGO, through the Heifer-in-Trust scheme. The aim was to train farmers about dairy production and enable farmers, particularly women, to acquire the means of production and so income.

Although total output may increase with herd size, farmers in this study kept small numbers of animals. It is possible that farmers chose to have small herds which can easily be managed as the majority of them practiced mixed farming (Lyimo et al. 2004). Residual calf suckling was practiced by most of the farmers, whereby one hindquarter is left unmilked or partially milked for the calf to suck. Milking was performed twice daily, morning and evening, and the calf was allowed to suck for 30-40 min after each milking. The amount of milk available to the calf was, therefore, determined by the quantity of milk remaining after milking. Many farmers rely on the sale of milk to provide income, and calves could, therefore, be easily starved since residual milk may be inadequate to meet the requirement of the calves. The impact of this is shown by the poor body condition of these calves. However, residual calf suckling has the advantage of reducing contamination, the feeding of cold milk to the calf and incidence of mastitis in the dam (Mdegela et al. 2004).

Farmers provided their calves with poor-quality food, mainly natural grass, and dry crop residues. The nutritional value (crude protein, mineral contents, and digestibility) of these feed stuffs has been found to be lower than of legumes (Mtengeti et al. 2008). There was scarcity of protein as there was no farmer who fed protein supplements to the calf during the study period. The proportion of feed stuffs and quantities offered was determined by their availability (Lyimo et al. 2004). The poor calf body condition observed in the present study could be the impact of this poor
Fig. 1 The sex distribution in the three age groups in 129 smallholder dairy farms in Tanzania

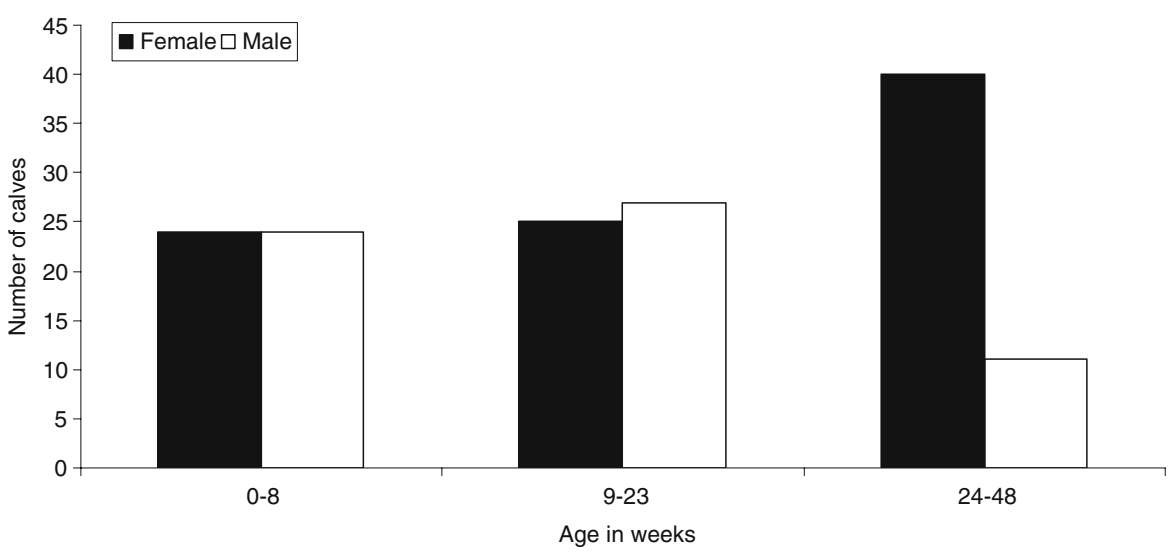


Table 3 Relationship between BCS and body weight by age group in smallholder dairy farms in Tanzania

\begin{tabular}{lllllc}
\hline Age group & $R^{2}$ & $\beta$ & SE & $P$ value & Number \\
\hline $0-8$ weeks & 0.35 & 0.01 & 0.002 & $<0.001$ & 42 \\
$9-23$ weeks & 0.02 & 0.001 & 0.001 & 0.310 & 44 \\
$24-42$ weeks & 0.19 & 0.004 & 0.001 & 0.004 & 40 \\
\hline
\end{tabular}

nutrition. However, maize stovers and rice straws can be utilized more efficiently by offering them to animals along with urea molasses blocks which have shown good results (Unal et al. 2005).

BCS showed a linear relationship with body weight for groups of calves younger than 9 weeks and older than 23 weeks of age but not for calves in the age group between 9 and 23 weeks. This is noteworthy and should be studied further. Such a relationship may be less pronounced at low BCS values (Berry et al. 2003). Thus, a closer relationship may be found between calves receiving their main energy requirements from milk as opposed to older calves which needs to rely on roughage of varying quality. After 8 weeks of age, one would expect the ruminant function to be established in these calves. The poor quality of the roughage fed to the calves may have impaired the development of the rumen in some of the calves. Thus, the relationship between BCS and live weight may be missing in the 9-23 week age group because of a high number of malnourished calves.

The sex distribution was skewed in male calves older than 23 weeks of age, and the BCS of the remaining male calves were lower than that of the females. It is hypothesized that male calves are more likely to experience suboptimal feeding and management than female calves leading to a higher incidence of malnutrition. During the interview, farmers expressed that the rearing of male calves was not profitable; therefore, these calves may have been sold for slaughter at a relatively young age, or even died of malnutrition, before they could be utilized for human consumption. The relationship between BCS and bodyweight among older calves in this study may be explained by the fact that this group is represented by female calves that are better cared for because of their higher value. Taken together, it is important to evaluate if feeding, and management, of male calves needs to be improved for animal welfare reasons as well as for more profitable utilization of beef for consumption.

Weaning age was higher than the age often found in other studies (Kehoe et al. 2007). Probably, this high weaning age was due to unavailability of good-quality feed. The earlier that rumen activity is initiated, the earlier the calf will be able to utilize substantial amounts of feed. Therefore, late weaning could have an overall negative effect on calf productivity.
The majority of the calves were kept in free stalls. Free stalls provide an opportunity for the farmer to feed, clean, and monitor the calves. However, another study revealed that calves raised in free stalls had a higher incidence of diseases than those raised in tie stalls (Gulliksen et al. 2009a). This may be a reason for the high occurrence of diarrhea reported by the farmers in this study.

In this study, about half of the cow-sheds had poor or very poor hygiene, with a poor drainage system, flat floors, and pot holes. Farmers frequently disposed of dung and waste materials in the vicinity of the animal housing which often resulted in unhygienic calf-rearing conditions. The housing hygiene affects calf health, especially for the calves with low immune status (Wudu et al. 2008). The present study showed that an increased emphasis should be placed on this issue by advisory personnel.

The main causes of calf death as perceived by the farmers were broad, but calf diarrhea was the most frequently reported cause which agrees with the findings of Gitau et al. (1994) and Wudu et al. (2008). Helminthosis and diarrhea were reported by the farmers as the most common disease conditions in the calves. This is in agreement with other reports worldwide (Lema et al. 2001; Wudu et al. 2008). Poor hygiene in the calf barns and inappropriate use of anthelmintics, observed during the study may have been responsible for the high occurrence of these conditions.

Most farmers were using albendazole for helminth control; which was probably due to its easy availability and/or low price. Due to its longevity, albendazole has shown higher degree of resistance to gastrointestinal nematodes in Tanzania (Keyyu et al. 2002; Chang'a and Kassuku 2006). Further research is needed to establish if this is the case in the study areas. The lack of scientifically based prophylactic anthelmintic treatment was revealed, which is similar to the findings of Addah et al. (2009). Most farmers dewormed their animals as frequently as every 3 months. Studies indicate that the burden of gastrointestinal nematodes was lowest at the end of the dry season, increased gradually through the rainy season to reach a peak at the end of the rainy season (Keyyu et al.

Table 4 Variance components of body condition score in 126 calves younger than 42 weeks of age, at farm, village, and district level on 129 smallholder dairy farms in Tanzania

\begin{tabular}{lllc}
\hline Random effect & Estimate & SE & $\begin{array}{c}\text { Proportion of total } \\
\text { variance (\%) }\end{array}$ \\
\hline District & $7.30 \mathrm{e}-09$ & $4.53 \mathrm{e}-06$ & 0 \\
Village & .0050396 & .0071783 & 4 \\
Farm & .1290376 & .0169308 & 96 \\
Total & 0.13408 & & 100 \\
\hline
\end{tabular}


2005). Therefore, there is a great potential towards targeted anthelmintic treatment and, thus, a reduction in the development of drug resistance.

ECF is also mentioned in this study as a cause of calf disease and death. In the tropics, the disease has been recognized to be one of the major constraints in livestock production (Swai et al. 2009; Kivaria and Noordhuizen 2009). The losses due to ECF can be lowered by intensive spraying, or dipping, using an effective acaricide (Mugisha et al. 2005), but use of acaricide was not investigated in this study. Pneumonia was also perceived by farmers as a cause of death in calves. Since the herd sizes were small and most of the barns had good ventilation, this perception is surprising as most of respiratory diseases associate with overcrowding and poor ventilation (Gulliksen et al. 2009b).

The farmers in Njombe have a longer tradition of keeping dairy cows when compared to those in Mvomero. Nearly all the households surveyed in Njombe practiced a mixed farming system, whereby crop cultivation, mainly maize, beans and Irish potatoes, and livestock (cattle, sheep, and goats) production were predominant. The uses of such systems are complementary between crop and livestock enterprises improve farm efficiency through nutrient cycling. Eighty-five percent of farms contributed with one animal only, making a differentiation between the proportions of total variance in BCS due to farm as opposed to animal level unfeasible. Not unexpectedly, the residual variance at this level accounted for $96 \%$ of total variance. The proportion of the variance in BCS residing at district level was found to be negligible. Instead a village effect became visible, indicating that skills in calf management differed between villages. Thus, progress could be achieved by approaches such as education and motivation of farmers and by improving livestock extension services. The findings of the present survey verifies that interventions for increasing calf health and performance should be focused on farm and animal level and that district differences were smaller than we had initially expected.

Acknowledgements The authors are grateful to the financial assistance from Norway through the Program for Agricultural and Natural Resources Transformation for Improved Livelihoods (PANTIL) project. The cooperation shown by farmers and field officers in Mvomero and Njombe districts should also be acknowledged.

Open Access This article is distributed under the terms of the Creative Commons Attribution Noncommercial License which permits any noncommercial use, distribution, and reproduction in any medium, provided the original author(s) and source are credited.

\section{References}

Addah, W., Baah, J., Tia, S. and Okine, E., 2009. Knowledge and practices of smallholder farmers and herdsmen in the use of acaricides and gastrointestinal anthelmintics in Ghana. Livestock Research for Rural Development, 21(11), 1-10

Berry, D.P., Buckley, F., Dillon, P., Evans, R.D., Rath, M. and Veerkamp, R.F., 2003. Genetic relationships among Body Condition Score, Body Weight, Milk Yield, and Fertility in Dairy Cows. Journal of Dairy Science, 86, 2193-2204

Chang'a, J.S. and Kassuku, A.A., 2006. Efficacy of commonly used anthelmintics in selected sheep farms in Arusha. Tanzania Veterinary Journal, 23 (2), 115-124

Chenyambuga, S.W. and Mseleko, K.F., 2009. Reproductive and lactation performance of Ayshire and Boran crossbred cattle kept in smallholder farms in Mufindi district, Tanzania. Livestock Research for Rural Development, 21(7), 1-7

Gitau, G.K., Mc Dermott, J.J., Waltner-Toews, D., Lissemore, K.D., Osumo, J.M. and Muriuki, D., 1994. Factors influencing calf morbidity and mortality in smallholder dairy farms in Kiambu District of Kenya. Preventive Veterinary Medicine, 21, 167-177

Gulliksen, S.M., Jor, E., Lie, K.I., Hamnes, I.S., Løken, T., Akerstedt, J. and Østeras, O., 2009a. Enteropathogens and risk factors for diarrhea in Norwegian dairy calves. American Dairy Science Association, 92, 5057-5066

Gulliksen, S.M., Lie, K.I., Løken, T. and Østeras, O., $2009 \mathrm{~b}$. Respiratory infections in Norwegian dairy calves. American Dairy Science Association, 92, 5139-5146

Kehoe, S.I., Dechow, C.D. and Heinrichs, A.J., 2007. Effects of weaning age and milk feeding frequency on dairy calf growth, health and rumen parameters. Livestock Science, 110(3), 267272

Keyyu, J.D., Kyvsgaard, N.C., Monrad, J. and Kassuku, A.A., 2009. Effectiveness of strategic anthelmintic treatments in the control of gastrointestinal nematodes and Fasciola gigantica in cattle in Iringa region, Tanzania. Tropical Animal Health and Production, $41,25-33$

Keyyu, J.D., Kassuku, A.A. Kyvssaard, N.C., Msalilwa, L.P. and Monrad, J., 2006. Cross sectional prevalence of helminth infections in cattle on traditional, small scale and large scale dairy farms in Iringa District, Tanzania. Veterinary Research Communication, 30(1), 45-55

Keyyu, J.D., Kyvsgaard, N.C., Monrad, J. and Kassuku, A.A., 2005. Epidemiology of gastrointestinal nematodes in cattle on traditional, small scale and large scale dairy farms in Iringa District, Tanzania. Veterinary Parasitology, 127(3/4), 285-294

Keyyu, J.D., Mahingika, H.M., Magwisha, H.B. and Kassuku, A.A., 2002. Efficacy of Albendazole and levamizole against nematodes of sheep and goats in Morogoro, Tanzania. Tropical Animal Health and Production, 32, 115-120

Kivaria, F.M. and Noordhuizen, J.P.T.M., 2009. Capture-recapture analysis of East Coast Fever in smallholder dairy herds in Dar es Salaam region of Tanzania. The Veterinary Journal, 184(2), 187193

Kusiluka, L.J.M., Karimuribo, E.D., Mdegela, R.H., Luoga, E.J., Munishi, P.K., Mlozi, M.R.S. and Kambarage, D.M., 2005. Prevalence and impact of waterborne zoonotic pathogens in water, cattle and humans in selected villages in Dodoma Rural and Bagamoyo districts, Tanzania. Journal of Physics and Chemistry of the Earth, 30, 818-825

Lema, M., Kassa, T. and Tegegne, A., 2001. Clinically manifested major health problems of cross bred dairy herds in urban and periurban production systems in the central highlands of Ethiopia. Tropical Animal Health and Production, 33 (2), 8593

Lyimo, H.L.N., Mtenga, L.A., Kimambo, A.E., Hvelplund T., Laswai G.H. and Weisbjerg, M.R., 2004. A survey on calf feeding systems, problems and improvement options available for the smallholder dairy farmers of Turiani in Tanzania. Livestock Research for Rural Development, 16 (23), 1-8 
Masanja, S.L. and Matovelo, J.A., 1993. Pathological and etiological observations associated with calf mortality in herds at Sokoine University of Agriculture, Morogoro, Tanzania. Tanzania Veterinary Journal, 13(2), 27-35

Mdegela, R.H., Kusiluka, L.J.M., Kapaga, M., Karimuribo, E.D., Turuka, F.M., Bundala, A., Kivaria, F., Kabula, B., Manjurano, A., Loken, T. and Kambarage, D.M., 2004. Prevalence and Determinants of Mastitis and Milk-borne Zoonoses in Smallholder Dairy Farming Sector in Kibaha and Morogoro Districts in Eastern Tanzania. Journal of Veterinary Medicine, 51, 123128

Mtengeti, E., Phiri, E., Urio, D.G., Mhando, Z., Mvena, R., Ryoba, R., Mdegela, R., Singh, M., Wetlesen, T., Løken, T. and Reksen, O., 2008. Forage availability and its quality in the dry season on smallholder dairy farms in Tanzania. Acta Agriculturae Scandinavica, 58, 196-204

Mugisha, A., McLeod, A., Percy, R. and Kyewalabye, E. 2005. Strategies, Effectiveness and Rationale of vectorborne disease control in the pastoralist system of South Western Uganda. Tropical Animal Health and Production, 37(6), 479-489

Shoo, M.K., Semvua, R.H., Kazwala, R.R. and Msola, P., 1992. A study on the cause-specific mortality rates of dairy calves on farms in the eastern zone of Tanzania. Preventive Veterinary Medicine, 13(1), 59-62

Swai, E., Karimuribo, E., Kambarage, D.M. and Moshy, W.E., 2009. A longitudinal study on morbidity and mortality in young stock smallholder dairy cattle with special reference to tick borne infections in Tanga region, Tanzania. Veterinary Parasitology, 160(1-2), 34-42

Swai, E.S., French, N.P., Karimuribo, E.D., Fitzpatrick, J.L., Bryant, M.J., Kambarage, D.M. and Ogden, N.H., 2007. Prevalence and determinants of Cryptosporidium spp. infection in smallholder dairy cattle in Iringa and Tanga Regions of Tanzania. Journal of Veterinary Research, 74(1), 23-29

Unal, Y., Kaya, I. and Oncuer, A., 2005. Use of urea molasses mineral blocks in lambs fed with straw. Preventive Veterinary Medicine, 156 (4), 217-220

Wildman, E.E., Jones, G.M., Wagner, P.E., Boman, R.L., Troutt H.F. and Lesch, T.N., 1982. A dairy cow body condition scoring system and its relationship to selected production characteristics. Journal of Dairy Science, 65, 495-501

Wudu, T., Kelay, B. Mekonnen, H.M. and Tesfu, K., 2008. Calf morbidity and mortality in smallholder dairy farms in Ada'a Liben district of Oromia, Ethiopia. Tropical Animal Health and Production, 40, 369-376 